УДК $811.161 .2: 81^{\prime 37}$

\title{
ЗМІСТ ПОНЯТТЯ ШАНТАЖ У ПРАВОВІЙ СФЕРІ ТА БУДЕННІЙ СВІДОМОСТІ
}

\author{
Людмила Білоконенко \\ Криворізький державний педагогічний університет \\ Kryvyi Rih State Pedagogical University \\ пр. Гагаріна, 54, Кривий Ріг, 50086, Україна \\ bk.ludmila1020@gmail.com
}

\begin{abstract}
Білоконенко Л. Зміст поняття шантаж у правовій сфері та буденній свідомості

Визначено, що у правому полі шантаж розпізнається через ознаку вимагання; лінгвістичні реєстрові бази фіксують вихід за межі криміналістики. Пояснено: вужчий правничий зміст терміна створив основу для ширшого побутового розуміння - залякування. Зазначено, що на рівні буденної свідомості шантаж сприймається як будь-яка вербальна дія щодо іншої людини із примусом; некримінальний шантаж може втілюватися прямими мовними засобами впливу чи грунтуватися на маніпулятивних діях. Описано результати лінгвістичного дослідження, за яким лише $20 \%$ респондентів витлумачують поняття, зважаючи на його правовий зміст, 80\% сприймають як номінування різних не протиправних впливів.
\end{abstract}

Ключові слова: поняття шантаж, комунікативна тактика, детермінологізація, правові норми, буденна свідомість.

Белоконенко Л. Содержание понятия шантаж в правовой сфере и обыденном сознании

Определено, что в правом поле шантаж распознается через признак вымогательство; лингвистические реестровые базы фиксируют выход за пределы криминалистики. Объяснено: узкое правовое содержание термина создало основу для более широкого бытового понимания - запугивания. Обозначено, что на уровне обыденного сознания шантаж воспринимается как любое вербальное деяние в отношении другого человека с принуждением; некриминальный шантаж может воплощаться прямыми языковыми средствами влияния или основываться на манипулятивных действиях. Описано результаты лингвистического исследования, за которым только $20 \%$ респондентов истолковывают понятие, учитывая его правовое содержание, $80 \%$ воспринимают как номинацию любого не противоправного давления.

Ключевые слова: понятие шантаж, коммуникативная тактика, детерминологизация, правовые нормы, обыденное сознание.

-9- Л. Білоконенко, 2019. 
Bilokonenko L. Content of the concept of blackmail in the legal sphere and ordinary consciousness

The author of the article determines that in the legal field, blackmail is recognized because of the qualification sign of a threat; in linguistic sources - as intimidation, demand, extortion, coercion, insistence, racketeering, constraint. The author explains that the narrower legal meaning of the term has created the basis for a fuller understanding of the phenomenon of intimidation by the threat of disclosure.

The author notes that at the level of ordinary consciousness, blackmail has an explanation that is significantly different from what is in the legislative sphere. It is perceived as any verbal action against another person with coercive. Non-criminal blackmail can be embodied by direct means of exposure or based on covert manipulative actions. The blackmailer's communicative behaviour makes it possible to talk about destructive communication. This process allows directive tacticalsituational promptings with a request, an order, a persistent request, an instruction, a directive, a ban; aggressive language acts, exclusive lexical content, structuring of expressions with certain syntactic unities, a system of stylistic means and techniques.

The article describes an experiment that made it possible to conclude: only $20 \%$ of respondents interpret the concept, using its narrow legal content, $80 \%$ perceive the meaning of blackmail through a set of their own sensual and mental images that appear being based on their nomination experience of illegal effects. Such results testify to the process of determinologization, understanding of the concept as a common phenomenon, which is a kind of psycho-emotional influence of one person on another in order to obtain any personal benefit.

Keywords: the concept of blackmail, communicative tactics, determinologization, legislative norms, ordinary consciousness.

\section{Постановка проблеми та їі зв'язок із важливими} науковими завданнями. Шантаж - тактика конфронтаційної комунікації. Поняття започатковане у кримінальному праві, але його активно використовують у повсякденному житті. Сьогодні його вузький юридичний зміст розширився, поняття усвідомлюють як різновид психоемоційного впливу однієї особи на іншу для отримання особистої вигоди.

Актуальність наукового розгляду поняття шантаж визначаємо, по-перше, складністю відбору, повторюваністю як відособлено, так і в поєднанні з іншими (нав'язливі пропозиції, погрози, вимоги, обман, накази, образи, приниження, заборони, глузування) тактиками; по-друге, потребою в лінгвістичному підході задля дослідження специфіки сприйняття в повсякденному житті. Аналіз уможливить з'ясування статусу шантажу в системі інших мовних дій у побутовій сфері, які 
спричиняють руйнівну (часто конфліктну) взаємодію людей. В інтерперсональному спілкуванні він $\epsilon$ особливим типом деструктивного контакту.

Аналіз останніх досліджень та публікацій. Оскільки поняття шантаж (від фран. chantage - вимагання) є широко відомим, то різні аспекти його потрактування неодноразово ставали об'єктом наукових розвідок у вітчизняній та закордонній науці. У юриспруденції розглядають його кримінально-правові характеристики (як різновид примусу або спосіб вимагання) [Habuda, Saviuk / Габуда, Сав'юк 2018], як злочин проти власності [Yakymova / Якимова 2015], феномен у політико-економічній сфері [Shevchuk/Шевчук 2017], відмежовують від інших споріднених понять [Yemielianov/ Смєльянов 2007; Semykina / Семикіна 2007] тощо. У цих сферах кваліфікація шантажу представлена у площині примусу, загрози розповсюдження інформації, певних дій/бездіяльності на позбавлення громадянина права на недоторканність приватного життя. Щодо мовних студіювань, то явище аналізовано в русистиці як мовленнєвий жанр [Panchenko, Nikodimova / Панченко, Никодимова 2018], визначено в системі категорії погроза [Voitsekhivska / Войцехівська 2014; Hohlova / Хохлова 2004] тощо. Проте ця тактика в україністиці в рамках різних комунікативних стратегій ще має широке коло питань для окремого лінгвістичного дослідження. Поняття шантаж уможливлює також його подальше вивчення з позиції лінгвоконфліктології та лінгвоекології.

Мета наукової розвідки: порівняння змістового наповнення поняття шантаж у правому полі та буденній свідомості.

Засадничі завдання: 3'ясувати зміст поняття шантаж у правому полі; визначити потрактування в лексикографічних джерелах; проаналізувати особливості сприйняття мовцями лексеми шантаж за результатами лінгвістичного дослідження.

Виклад основного матеріалу дослідження. У ст. 3 Конституції України зазначено: “Людина, іiі життя і здоров'я, честь і гідність, недоторканність і безпека визнаються в Україні найвищою соціальною цінністю" [Konstytutsiia / Конституція]. У демократичній правовій державі забезпечується право 
громадянина на недоторканність приватного життя, особисту таємницю, передбачена відповідальність за певні суспільно небезпечні дії, до яких зараховано й шантаж. Найбільший прояв він отримує через склад злочину вимагання: Кримінальний кодекс України (далі - КК) визначає, що ним є вимога передачі або пошкодження чи знищення чужого майна, погроза насильства, обмеження прав, свобод або інтересів осіб, розголошення відомостей, які особи хочуть зберегти в таємниці [Kryminalnyi / Кримінальний : ст. 189]. Спробу криміналізції цього явища, певний рух до гармонізації нашого законодавства 3 європейським доводить той факт, що у 2018 році у Верховній Раді України був зареєстрований проєкт Закону "Про внесення змін до Кримінального кодексу України (щодо кримінальної відповідальності за шантаж)", де запропоновано доповнити кодекс ст. 189-1 “Шантаж”. Тож такий вид злочинного діяння в суспільстві $\epsilon$ визначеним, із соціальним підгрунтям, a відповідальність за цей спосіб вчинення злочину регулюють кримінально-правові норми.

Однак у юридичному полі поняття позбавлене чітких кордонів, тлумачиться через інші поняття або його кваліфікують у системі інших суспільно-небезпечних дій. У коментарях до КК України (далі - ККУ) зазначено: шантаж - це погроза розголошення компрометувальних (дійсних або наклепницьких) відомостей про особу; загроза насильства; шантажист має на меті певну матеріальну, політичну або ін. вигоду [Kryminalnyi / Кримінальний $2003: 423$ ]; погроза викриття, розголошення відомостей, які ганьблять людину, щоб домогтися якихось результатів; примус особи до вигідної для шантажиста поведінки [Naukovo-praktychnyi / Науково-практичний 2018: 299]. Як бачимо, це явище у правому полі першорядно визначають через кваліфікаційну ознаку загроза / погроза з вимаганням матеріальної, фізичної або ін. поступки, що спричиняе шкоду об'єкту вимагання.

Нечіткість визначення могло б дещо увиразнити тлумачення у сфері конфліктології, де шантаж визнано за тактику конфронтаційної стратегії. І це є виправданим, оскільки iii використання задля посилення впливу на об'єкт вимагання 
може актуалізувати негативні наслідки. Через те, що тактика передбачає для контактера “вибір” лише між негативними умовами / обставинами, той і сприйняття таких вимог не може бути конструктивним. У конфліктології визнано кілька видів шантажу: 1) сімейно-побутові, які $\epsilon$ емоційною формою міжособистісного маніпулювання; 2) соціальні - різні форми тиску соціуму на особистість, коли взаємодія осіб між собою й індивіда 3 суспільством та державою передбачає дотримання багатьох вимог, а їх невиконання спричиняє негативні наслідки для людини (напр., утримання у в'язниці); 3) політикоекономічні (технологія боротьби за владу), до них зараховують i політичний шантаж - девіантна діяльність, спрямована на реалізацію цілей політичного суб'єкта / об'єкта; 4) ідеологічні, коли різними інструментами (напр., ЗМІ) формують громадську думку з важливих питань і коригують курс адміністрації країни. Для усвідомлення змісту поняття характер цих відомостей може відігравати хіба що допоміжну роль, проте переконливо доводить: у цієї тактики є конфліктногенеруючі властивості, вона утверджується в різних сферах суспільного життя.

Представлена дослідницька проблема потребує оцінки явища в комунікативно-прагматичному аспекті, що демонструє тісний зв'язок мовної організації шантажу та мети застосування. Вплив на об'єкт може реалізувати одинична мовна акція або складна вербальна структура, посилена іншими позамовними кроками. Оскільки в його основі - поняття загроза / погроза, то не складно усвідомити: шантажист має певне особливе право на щось, і $з$ тим - переваги над об'єктом вимагання. Адресант обирає вигідний для себе варіант розвитку комунікації незалежно від соціального статусу, офіційності чи неофіційності стосунків, адже, як уважає, може нав'язувати певний тип комунікативного контакту. Це вможливлюють, по-перше, директивні тактикоситуативні спонукання 3 вимогою, наказом, наполегливим проханням, вказівкою, розпорядженням, забороною, коли позиція контактера не береться до уваги. По-друге, агресивними мовними діями 3 системним використанням жорстких комунікативних тактик, особливим лексичним наповненням, структуруванням висловлення в певних синтаксичних єдностях, системою 
стилістичних засобів і прийомів. Постійне використання загрози, негативний вплив на емоційний стан об'єкта вимагання, кваліфікується як неекологічна комунікація.

Важливий момент у виявленні змісту поняття - робота в царині лексикографії. Словникове витлумачення лексеми шантаж уможливлює з'ясування ії зв'язку з іншими близькими поняттями, дає змогу ідентифікувати смислову домінанту, хоча, як ми вже бачили, вона не однакова для різних сфер.

Словник української мови подає значення лексеми шантаж: залякування погрозою викрити або розголосити 3 певною метою факти, відомості, які можуть скомпрометувати, зганьбити кого-небудь [Slovnyk / Словник 1980:405]. У цій реєстровій базі значення розкрите через базове - залякування (викликати в кого-небудь страх, переляк; робити кого-небудь боязким, лякливим [Slovnyk / Словник 1972 : 178]). Зауважимо, що у словниковій статті поняття загроза / погроза не $\epsilon$ ключовими, як у ККУ, а лексема вимагання (1. Настирливо просити що-небудь у когось. 2. Ставити перед ким-небудь якусь вимогу; категорично пропонувати зробити щось. 3. Зобов'язувати до чого-небудь, змушувати робити саме так [Slovnyk / Словник 1970 : 427]), як у ст. 189 КК, узагалі відсутня.

У словнику іншомовних слів: шантаж - це залякування погрозою розголошування відомостей, які можуть скомпрометувати кого-небудь, щоб одержати якусь вигоду [Slovnyk / Словник $2000: 650]$, де знову визначаємо ключове слово залякування.

У словнику синонімів подано: шантаж - погроза, вимога, наполягати [Karavanskyi / Караванський 2004:464]. Тут ця одиниця мови перебуває в системі: погроза - грозьба, грізьба, похвальба, нахвалка, похвалка, погрожування, залякування; (компрометація в разі невиконання вимог), шантаж [там само : 304]; вимога - домагання, вимагання, наполягання; (безапеляційна), наказ [там само: 43]; наполягання: дія за значенням наполягати - напосідати, домагатися, вимагати; (на чому) твердо стояти, напирати, налягати [там само : 225].

У синонімічних рядах інших гніздових слів також наведено лексеми, що логічно співвідносимо зі словом

(с) Л. Білоконенко, 2019. 
шантаж. А саме: примус - принука, силування, змушування, примушування, /3/неволення, приневолення [там само : 329]; загроза - (словесна) погроза, погрожування, нахваляння, грозьба [там само: 119]; залякування: дія за значенням залякувати лякати, страхати, застрашувати, тероризувати [там само : 124]. Думаємо: цей перелік можна доповнити й лексемою рекет злочинне вимагання чужих доходів, здирство шляхом залякування чи грубого насильства [там само:492], оскільки тлумачення містить раніше не реєстровану лексему здирство наполегливе вимагання або домагання чого-небудь шляхом примусу, погроз, насильства [Slovnyk / Словник 1972 : 537].

Як бачимо, матеріал словникового корпусу дає змогу встановити смислові нюанси лексеми шантаж і ії зв'язок 3 іншими близькими поняттями: залякування, загроза, погроза, погрожування, вимога, здирство, наполягання, примус, примушування, принука, змушування, рекет, силування. Цей перелік вбирає трактування КК - вимагання та ККУ - загроза (погроза), вимагання, вимога, примус, хоча вужчий правничий зміст створив підгрунтя для ширшого побутового розуміння залякування, а не навпаки. У правничій сфері акцентовано на поєднанні складників: загроза розголошення компромату та вимагання матеріальних цінностей, юридично - це намір на психологічний, фізичний вплив на об'єкт шантажу, тобто засіб скоєння злочину.

Звернення до лінгвістичних реєстрових баз показало: лексема шантаж за межею кримінальної сфери розширює своє значення та номінує різні види некримінального впливу. На рівні лексикографії є пояснення, що значно вирізняється від укоріненого в теорії кримінального права, трактуючись як будьяке залякування із примусом. Некримінальний шантаж усвідомлюється як явище, що не складно декодувати, шаблонне та передбачуване за механізмом реалізації та мовними кроками індивідів, один $з$ яких припускає своє право нав'язувати іншому певну модель розвитку події.

Зважаючи на різні стратегії міжособистісного спілкування, шантаж може: 1) втілюватися прямими засобами впливу; 2) грунтуватися на прихованих маніпулятивних діях. 
У щоденному спілкуванні, коли шантаж переважно осягається як залякування погрозою розголошення інформації, тобто співвідноситься 3 мовленням, характер його реалізації $\epsilon$ прямим. Адресант використовує структури 3 "обіцянкою" неприємностей у разі невиконання адресатом певних дій. Однак ці негативні наслідки можуть бути визначені по-різному. Нечітко окреслену погрозу, наприклад, реалізують конструкції зі сполучниками: якщо (якщзо...mо, коли...mо), або...або та дієслова стану, дії, що передбачають їхнє найрізноманітніше потрактування: дізнаєшся, зрозумієш, пожалкуєш, пошкодуєш, запам'ятаєш, спробуєш, побачиш, здивуєшся, не захочеш, не повіриш, отримаєи і т. ін. (Якщо не зробии (не скажеш, не принесеш і т. ін.) - (то) пожсалкуєш; Або ти негайно повернешся додому, або отримаєи від мене). Проте сполучники можуть бути відсутні, що робить складнішим розуміння змісту погрози та способу його вираження. Така побудова ускладнює причиннонаслідкові зв'язки між погрозою та “обіцянкою” і спонукає індивіда докласти більше зусиль для декодування інтенції адресанта. В експліцитній погрозі застосовують одиниці мови, що мають чіткий семантичний формат стосовно впливу на контактера й дій щодо нього: (Або ти прибереш у кімнаті, або я все розкажу татові; Доки не зробиш домашне завдання, комп'ютер не отримаєш). Ці акції містять чимало дієслів, які, вказуючи на "покарання", характеризуються значеннями, що відбивають характер дії, особливості іiі перебігу, джерело та кінцевий результат.

Пряме спонукання часто містять розширені пояснення погрози, реалізовані складними реченнями або кількома реченнями. Це акт залякування, у якому адресант однозначно висловлюється щодо наслідків невиконання свого волевияву (Слухай мене, Оскаре! Ми заберемо июю дитину $і$ виховаємо, як свою! I лише спробуй комусь розповісти про те, як ми ї̈ знайшли! Три шкури спущу, ти мене знаєш! Баронесі поскаржуся на тебе (Бойлук Ю. Коли розквітне лілея); < ..> сам дядько Григорій сказав своєму Михайлові, щуо коли ти будеш з тим босяком сходиться <..> то я тебе приб'ю (Тютюнник Ю. Від “Двійки” до ГПУ); - П'ять тисяч баксів! 
Покладеш до мосї сумки! Як не побачу - повернуся за хвилину! Надворі мене чекають. Не віриш? А ти підійди до вікна! Глянь! Троє у шкіряних куртках <..> - Ангеліночко. Принеси гроші, - почула тихий <..> голос матері. Ліда приголомшено глянула на Іветту. - Мамо... Не можна... <..> Це шантаж⿻ (Дашвар Люко. Мати все). У такому разі тиск не обмежений залякуванням погрозою розголошення компромату. Вплив на об’єкт уможливлює й “обіцянка” заподіяння не лише морального чи матеріального, а й фізичного покарання адресата чи близьких йому людей. Щодо цього зазначимо: шантаж реалізується вербально, коли ж особа орієнтована не лише на вербальні, а й на фізичні дії, це є погроза.

Погроза непрямої форми впливу припускає маніпуляцію, оскільки наголошує на важливій ознаці шантажу - використанні почуттів людини для досягнення мети, тобто передбачає раціональний вплив на ії емоційну сферу, напр.: Марк подивився на мене поглядом зрадника і сказав: - Якщо ти не підеш, я викличу тих хлопців... - Яких хлопців? - відсахнувся я. - Тих, щц наводять фен-иуй. Зачищають енергетичне поле будинку від усіляких там <..> завад. Вони приборкали одну твою колегу з півроку тому <...> - Ти не зробиш таке зі мною. Зроблю (Ряполова М. Звідки беруться янголи).

Для уточнення потрактування поняття шантаж у свідомості мовців було проведене лінгвістичне дослідження (у формі опитування) зі студентами-філологами віком від 18 років. Інформантам було запропоновано перейти від словастимулу шантаж до будь-якого іншого слова, яке їм видається відповідним першому за змістом (отримано 160 реакцій). Серед масиву даних розмежовано типи реакцій, що засвідчили рівень осягання поняття носіями мови, яких ми опитали.

Виявлено лише $20 \%$ відповідей, у яких респонденти витлумачують поняття так само, як у правничій сфері: загроза (погроза), вимагання, вимога (вар. ультиматум), примус, намір, вплив, злочин (вар. кримінал, насилля, грабіж, провокачія). Інші сприймають як тиск (вар. важіль) (майже 5\%; таке визначення подається в конфліктології); викриття, ганьба, домагання, примушування, тероризування (майже 5\%; ці ж слова ми 
фіксували в лексикографічних джерелах, водночас реакції залякування, наполягання, здирство відсутні). Близько 70\% пояснили лексему через сукупність власних почуттєвих i розумових образів, що безпосередньо з'являються перед ними у внутрішньому досвіді: агресія, безпорадність, безчестя, біль, горе, грубість, жадібність, заздрість, зло, маніпуляиія, недовіра, неправда, нечесність, обман (вар. блеф, шахрайство), образа, nідлість, niдстуn, сила, страх, хитрість; ця група інформантів сприймає іï лише як номінування різних видів не протиправних впливів. Поза будь-яким сумнівом, слово шантаж сьогодні “пристосувалося" до повсякденно-побутової сфери, а процес детермінологізації розширив його семантику.

\section{Висновки та перспективи подальших наукових} розвідок. Поняття шантаж у правничій сфері тлумачать як вимагання, погроза, це злочинний намір, у конфліктології тиск, у лінгвістичних джерелах визначають через кваліфікаційні ознаки: залякування, вимога, здирство, примус, наполягання, силування. Вужчий правничий зміст створив підгрунтя для ширшого побутового розуміння. Лексема шантаж за межею правової сфери розширила значення та номінує різні види некримінального впливу. Некримінальний шантаж може втілюватися прямими засобами впливу чи грунтуватися на маніпулятивних діях. Комунікативна поведінка шантажиста дає змогу говорити про подію деструктивної комунікації. Проведене дослідження свідчить: лише $20 \%$ респондентів витлумачують поняття, зважаючи на його вузький правовий зміст, інші сприймають як номінування різних видів не протиправних впливів. Тож на рівні буденної свідомості шантаж має пояснення, що значно вирізняється від укоріненого у правничій сфері, сприймаючись як будь-яка дія щодо іншої людини із примусом. Перспективи подальшого дослідження вбачаємо в поглибленому аналізі способів і засобів його мовної реалізації.

\section{Література}

1. Войцехівська Н. К. Засоби вираження погрози в українському конфліктному діалогічному дискурсі. Гуманітарна освіта у технічних вищих навчальних закладах. 2014. Вип. 30. С. 17-30.

2. Габуда А. С., Сав’юк О. В. Криміналізація шантажу. Науково-

(с) Л. Білоконенко, 2019. 
інформаційний вісник Івано-Франківського університету права імені Короля Данила Галицького : Право. 2018. № 5 (17). С. 151-155.

3. Смєльянов В. П. Щодо визначення предмету злочину та класифікації об'єктів злочинів. Боротьба з організованою злочинністю і корупцією (теорія і практика). 2007. Вип. 17. С. 225-232.

4. Караванський С. Й. Практичний словник синонімів української мови. 2-е вид. Київ : Українська книга, 2004. 448 с.

5. Конституція України. URL : https://zakon.rada.gov.ua/laws/show/254\% D0\%BA/96-\%D0\%B2\%D1\%80 (дата звернення: 22.09.2019).

6. Кримінальний кодекс України. URL : https://zakon.rada.gov.ua/ laws/show/ 2341-14/page (дата звернення: 21.09.2019).

7. Кримінальний кодекс України : науково-практичний коментар / Ю. В. Баулін, В. І. Борисов, С. Б. Гавриш та ін. Київ, 2003. 1196 с.

8. Науково-практичний коментар до Кримінального кодексу України / Д. С. Азаров, В. К. Грищук та ін. Київ, 2018. 1104 с.

9. Панченко Н. Н., Никодимова А. Д. Шантаж: речевой акт VS речевой жанр. Жанры речи. 2018. № 2 (18). С. 112-118.

10. Семикіна Л. О. Відмежування вимагання як злочину 3 ознаками тероризування від тероризму. Боротьба з організованою злочинністю $i$ корупцією (теорія і практика). 2007. Вип. 16. С. 111-119.

11. Словник іншомовних слів / уклад. С. Морозов, Л. Шкарапута. Київ : Наукова думка, 2000. 680 с.

12. Словник української мови : в 11-ти т. / АН УРСР. Інститут мовознавства ; за ред. І. К. Білодіда. Київ : Наукова думка, 1970-1980.

13. Хохлова Н. В. Способы и средства реализации коммуникативной категории угрозы в русском и английском языках : дис. ... канд. филол. наук. Волгоград, 2004. 198 с.

14. Шевчук I. В. Рейдерство та корпоративний шантаж (грінмейл) як загроза економічній безпеці України. Університетські наукові записки. 2017. № 2. С. 231-240.

15. Якимова С. В. Вимагання у зв'язку 3 підкупом за кримінальним законодавством України. Вісник Національного університету “Львівська політехніка”. Юридичні науки. 2015. № 825. С. 355-359.

\section{References}

1. Voitsekhivska N. K. Zasoby vyrazhennia pohrozy v ukrainskomu konfliktnomu dialohichnomu dyskursi. Humanitarna osvita $u$ tekhnichnykh vyshchykh navchalnykh zakladakh. 2014. Vyp. 30. S. 17-30.

2. Habuda A. S., Saviuk O. V. Kryminalizatsiia shantazhu. Naukovoinformatsiinyi visnyk Ivano-Frankivskoho universytetu prava imeni Korolia Danyla Halytskoho : Pravo. 2018. № 5 (17). S. 151-155.

3. Yemielianov V. P. Shchodo vyznachennia predmetu zlochynu ta klasyfikatsii obiektiv zlochyniv. Borotba z orhanizovanoiu zlochynnistiu $i$ koruptsiieiu (teoriia $i$ praktyka). 2007. Vyp. 17. S. 225-232.

4. Karavanskyi S. Y. Praktychnyi slovnyk synonimiv ukrainskoi movy. 2-e vyd. Kyiv : Ukrainska knyha, 2004. 448 s. 
5. Konstytutsiia Ukrainy. URL : https://zakon.rada.gov.ua/laws/show/254\% D0\%BA/96-\%D0\%B2\%D1\%80 (data zvernennia: 22.09.2019).

6. Kryminalnyi kodeks Ukrainy. URL : https://zakon.rada.gov.ua/laws/show/ 2341-14/page (data zvernennia: 21.09.2019).

7. Kryminalnyi kodeks Ukrainy : naukovo-praktychnyi komentar / Yu. V. Baulin, V. I. Borysov, S. B. Havrysh ta in. Kyiv, 2003. 1196 s.

8. Naukovo-praktychnyi komentar do Kryminalnoho kodeksu Ukrainy / D. S. Azarov, V. K. Hryshchuk ta in. Kyiv, 2018. 1104 s.

9. Panchenko N. N., Nikodimova A. D. Shantazh: rechevoy akt VS rechevoy zhanr. Zhanryi rechi. 2018. № 2 (18). S. 112-118.

10. Semykina L. O. Vidmezhuvannia vymahannia yak zlochynu z oznakamy teroryzuvannia vid teroryzmu. Borotba z orhanizovanoiu zlochynnistiu i koruptsiieiu (teoriia i praktyka). 2007. Vyp. 16. S. 111-119.

11. Slovnyk inshomovnykh sliv / uklad. S. Morozov, L. Shkaraputa. Kyiv : Naukova dumka, 2000. $680 \mathrm{~s}$.

12. Slovnyk ukrainskoi movy : v 11-ty t. / AN URSR. Instytut movoznavstva ; za red. I. K. Bilodida. Kyiv : Naukova dumka, 1970-1980.

13. Hohlova N. V. Sposobyi i sredstva realizatsii kommunikativnoy kategorii ugrozyi v russkom i angliyskom yazyikah : dis. ... kand. filol. nauk. Volgograd, 2004. 198 s.

14. Shevchuk I. V. Reiderstvo ta korporatyvnyi shantazh (hrinmeil) yak zahroza ekonomichnii bezpetsi Ukrainy. Universytetski naukovi zapysky. 2017. № 2. S. 231-240.

15. Yakymova S. V. Vymahannia u zviazku z pidkupom za kryminalnym zakonodavstvom Ukrainy. Visnyk Natsionalnoho universytetu "Lvivska politekhnika”. Yurydychni nauky. 2015. № 825. S. 355-359. 